\title{
The Effect of the COVID-19 Pandemic on the Epidemiology of Hip Fractures
}

\author{
Kalça kırıklarının epidemiyolojisine Covid-19 pandemisinin etkisi
}

\author{
Sefa Akt1 ${ }^{1 *}$, Deniz Çankaya ${ }^{1}$ \\ 1.Aksaray University Education and Research Hospital: Ortopedic and Traumatology Department Aksaray, Turkey
}

\begin{abstract}
Aim: This study aimed to compare the epidemiology of hip fractures in an elderly population in 6 months of the COVID-19 pandemic and the same 6-month period in the previous year to be able to reveal how the decrease in community activity beyond normal seasonal habits because of the pandemic had affected the incidence of fractures in the elderly patient population.

Methods: A comparison was made of the data of patients who presented at our hospital with a hip fracture between 1 April 2020 and 30 September 2020, and those who presented in the same 6-month period in 2019 before the pandemic. Comparisons were made in respect of epidemiology, treatments applied, complication rates and mortality. The demographic data of the patients were examined, and those presenting during the pandemic were evaluated in respect of the presence of COVID-19 infection.

Results: A total of 78 patients were treated in the defined study period in 2020 and 71 in the equivalent period in 2019 before the pandemic. No statistically significant change was found in the number of hip fractures in $2020(p>0.05)$. No statistically significant difference was observed between the demographic data of the patients, the ASA scores, the treatment methods, or the mortality rates in the two periods ( $p>0.05$ for all).

Conclusions: The most significant finding of this study was that there was no decrease in the number of patients with hip fracture during the pandemic in 2020, compared to the equivalent period in 2019. The increase in pulmonary complications during the pandemic period demonstrates the need for special care conditions in elderly patients with hip fractures, which are still seen at a high rate despite the pandemic.
\end{abstract}

Keywords: Coronavirus, Hip fractures, pandemic

\section{öz}

Amaç: Normal mevsimsel sürenin ve normal insan alışkanlıklarının ötesinde toplum aktivitesi azalmasının, yaşı hasta popülasyonunda görülen kırıkların insidansının nasıl etkilediğini ortaya koymak için pandeminin 6 aylık dönemindeki kalça kırıklarının epidemiyolojisini, bir önceki yıldaki aynı 6 aylık zaman aralığına göre karılaştırmayı ve pandemiye bağlı değişiklikleri ortaya koymayı amaçladık.

Yöntemler: Çalışmamızda 1 Nisan 2020 ile 30 Eylül 2020 tarihleri arasındaki pandeminin 6 aylık süresi zarfında hastanemize başvuran kalça kırıkları ile 2019 yılının aynı döneminde hastanemize başvuran kalça kırıkları, epidemiyolojileri ve uygulanan tedaviler, komplikasyon oranları ve mortalite yönünden karşılaştırıldı. Hastaların demografik verilerine bakıldı. Pandemi döneminde kalça kırığı ile başvuran hastaların eşlik eden COVID 19 enfeksiyonu olup olmadığı değerlendirildi. Bulgular: Pandemi öncesi 2019 yılında 71 hasta tedavi edilirken 2020 yılında 78 hasta tedavi edilmişti. 2020 yılında kalça kırık sayısının istatistiksel olarak değişmediği bulundu ( $p>0.05)$. Tedavi yöntemleri açısından istatistiksel olarak anlamlı fark gözlenmedi ( $p>0.05$ ). 2019 ve 2020 yılları arasında demografik verileri açısından istatistiksel olarak anlamlı fark saptanmamışı ır ( $p>0.05$ ). 2019 ve 2020 yılları arasında hastaların ASA skorları açısından anlamlı fark saptanmamıştır ( $p>0.05) .2019$ ve 2020 yılları arasında mortalite oranları açısından anlamlı fark saptanmamıştır ( $p>0.05)$.

Sonuçlar: Çalışmamızın en önemli bulgusu 2020 yılında pandemi döneminde kalça kırığı olan hasta sayısının 2019 yılına göre düşmemesidir. Pandemi döneminde pulmoner komplikasyonlardaki artış, yaşlı hasta popülasyonunda pandemiye rağmen yüksek oranda görülen kalça kırıkı hastalarda özel bakım şartlarının gerekliliğini ortaya koymaktadır.

Anahtar Kelimeler: coronavirus, kalça kırıkları, pandemi

Received: 18.02.2021 Accepted: 07.06.2021 Published (Online):31.12.2021

*Corresponding Author: Sefa AKTI, Aksaray University Education and Research Hospital: Ortopedic and Traumatology Department Aksaray, Turkey.+905056577170, sefa.akti@gmail.com

ORCID: 0000-0001-8873-1358

To cited: Aktı S, Cankaya D. The Effect of the COVID-19 Pandemic on the Epidemiology of Hip Fractures. Acta Med. Alanya 2021;5(3):270-275 doi:10.30565/medalanya.866332 


\section{INTRODUCTION}

$F^{\circ}$ ollowing the outbreak of the novel coronavirus (SARS-CoV-2) determined as an agent of pneumonia resulting in death, Wuhan, China, in December 2019, the coronavirus disease 2019 (COVID-19) spread rapidly around the world and was declared a global pandemic by the World Health Organisation on 11 March 2020. The first case in Turkey was recorded on 11 March 2020. With no preventative vaccination or definitive treatment, Turkey and the whole world started to implement quarantine precautions with the closure of public spaces and curfews [1].

The COVID-19 pandemic caused by the SARSCoV-2 virus had a significant effect on life throughout the whole world. People had to abandon various social habits because of quarantine, and by spending more time at home, activity levels significantly decreased $[2,3]$ This decreased level of activity has been reported to reduce the incidence of several fractures $[1,4]$. However, there are also reports in literature that the rate of hip fractures in the elderly population, which are generally the result of a fall in the home, has not changed [4].

Hip fractures have high mortality and morbidity in the elderly patient population $[5,6]$. SARS-CoV-2 virus infection is known to lead to more severe disease and higher mortality rates in the elderly population. Hip fracture mortality rates in the elderly population have been reported to have increased during the COVID-19 pandemic [7]. The outcomes have shown differences between countries and hospitals according to the effects of the pandemic and population distribution $[8,9]$.

Therefore in this study, the incidence of hip fractures seen in an elderly patient population in a 6-month period of the pandemic were evaluated to reveal the effect of reduced community activity beyond the normal seasonal habits. This study aimed to compare the incidance of hip fractures in a 6-month period of the pandemic with the equivalent 6 -month period in the previous year, to determine changes related to the COVID-19 pandemic.

\section{MATERIAL AND METHOD}

The first case of COVID-19 was recorded on 11 March 2020, and from that date, quarantine precautions started to be implemented throughout the whole country. In the study, patients who presented at our hospital with a proximal femur fracture in the 6-month pandemic period of 1 April 2020 - 30 September 2020, were compared with patients who presented in the equivalent period in 2019 in respect of the treatments applied and complication rates.

The study included all patients aged $>65$ years with a fracture of $31 \mathrm{~A}, 31 \mathrm{~B}$, and $31 \mathrm{C}$ according to the $A O$ classification (Figure 1). Patients with a pathological fracture, periprosthetic fracture or multiple fractures were excluded from the study. A total of 154 patients with hip fractures were identified in the defined 6-month periods of 2019 and 2020. A total of 5 patients were excluded due to the unavailability of data of hip radiographs at the time of presentation, BMI, or operation data.

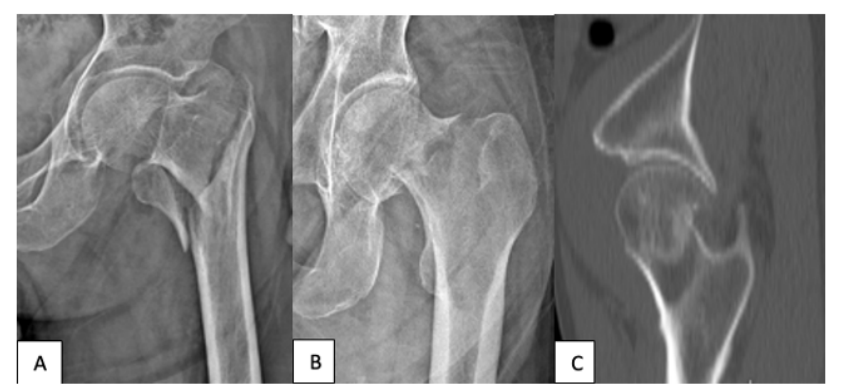

Figure 1. Anteroposterior radiograph of an 84-year old female patient with $31 \mathrm{~A}$ fracture $(\mathrm{A})$, anteroposterior radiograph of a 74-year old male patient with 31B fracture (B), and Computed tomography slice of a 81year old male patient with $31 \mathrm{C}$ fracture $(\mathrm{C})$.

The data of patients with a hip fracture were retrieved from the hospital electronic database according to the defined study criteria. The patients were evaluated in respect of age, gender, body mass index (BMI), date of presentation, fracture side and fracture type. The treatment methods applied to the patients were also examined (conservative or which surgical method), the American Society of Anaesthesiologists (ASA) scores of the patients treated surgically, the presence of COVID-19 infection, whether or not there were findings on pulmonary radiographs of acute pulmonary complications requiring oxygen support preoperatively or postoperatively, time from admission to surgery, anesthesia type, a requirement for intensive care, the presence 
of venous thromboembolism, dislocation, deep infection in the operation site, and in-hospital mortality rates.

Approval for the study was granted by the Local Ethics Committee.

\section{Statistical Analysis}

Data obtained in the study were analyzed statistically with IBM SPSS vn. 25.0 software (IBM SPSS Statistics for Windows, Version 22.0. Armonk, NY, USA). Conformity of the data to normal distribution was assessed with the Shapiro Wilk test. To compare variables in groups of nonparametric data, the Mann Whitney U-test was applied. For the comparison of categorical data, the Chi-square test was used. A value of $p<0.05$ was accepted as statistically significant for all the parameters.

\section{RESULTS}

A total of 154 patients with hip fractures were identified in the defined 6-month periods of 2019 and 2020. A total of 5 patients were excluded due to the unavailability of data of hip radiographs at the time of presentation, BMI, or operation data. Thus, the study included 149 patients, as 71 in 2019, and 78 in 2020. There was found to be no change in the frequency of hip fractures seen in 2020 compared to $2019(p=0.99)$. The demographic data of the patients are shown in Table 1. No statistically significant difference was determined between the patient groups of both years in respect of age $(p=0.97)$.

The distribution of patients according to age and date of presentation is shown in Figure 2. No significant difference was determined between 2019 and 2020 in respect of in-hospital mortality rates $(p=0.56)$. Mortality developed in $5(7 \%)$ patients during hospitalization in the study period of 2019 , and $8(10 \%)$ patients in 2020 .

When the patients who presented at the Emergency Department with a hip fracture in 2019 and were planned to undergo surgical treatment were evaluated in respect of ASA scores, ASA 2 was determined in $35(50.7 \%)$ patients, ASA 3 in 30 $(43.5 \%)$, and ASA 4 in 4 (5.8\%). In 2020, the ASA scores were ASA 2 in $38(50.7 \%)$ patients, ASA 3 in $32(43 \%)$ and ASA 4 in $5(6.3 \%)$. No statistically significant difference was determined between the two-year groups of patients in respect of ASA scores $(p=0.976)$. Of the patients who presented during the pandemic in 2020, no COVID-19 test was applied to $24(30.8 \%)$ patients, COVID-19positivity was determined in $8(10.2 \%)$ patients, and the test was negative in 46 patients.

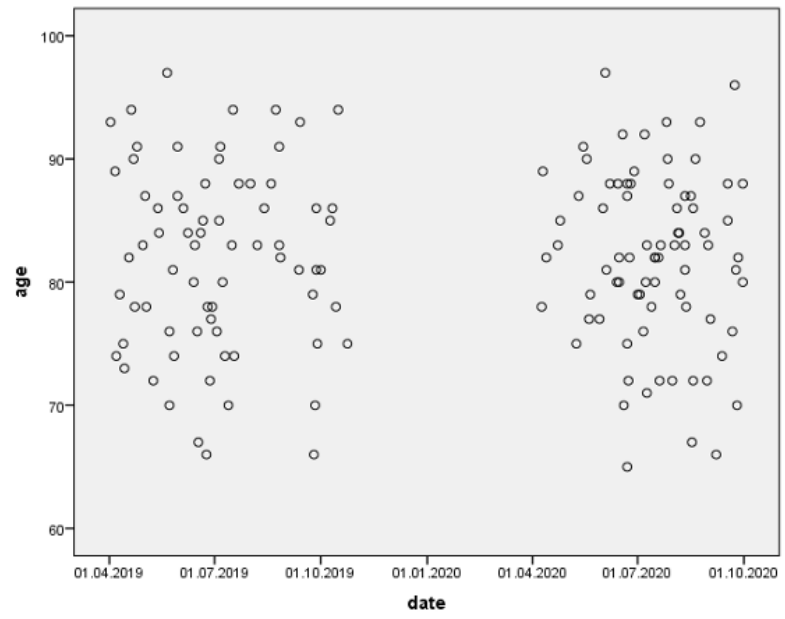

Figure 2. Chart of the patients presentation at hospital according to the date and age in 2019 and 2020

Of the patients with a positive COVID-19 test, conservative treatment was applied to 2 patients and 3 patients with a mean age of 81 years were re-tested and on obtaining a negative result, were operated on at mean 12.3 days later. Of these, mortality was observed in 1 patient. In 1 patient, respiratory failure developed, and after follow-up in the Intensive Care Unit (ICU), this patient was discharged on the 17th day. In the third patient, no symptoms were observed during follow-up and the patient was discharged on the 11th day. The other results of the patients in 2019 and 2020 are summarised in Table 2.

Table 1. Demographic data

\begin{tabular}{|l|l|l|l|l|l|}
\hline \multirow{2}{*}{ Mean age (years) } & \multicolumn{2}{|l|}{2019} & \multicolumn{2}{l}{2020} & \multirow{2}{*}{ p value } \\
\cline { 2 - 5 } & Mean & SD & Mean & SD & \\
\cline { 2 - 5 } & 81.94 & 7.5 & 81.88 & 7 & 0.970 \\
\hline Number of patients & 71 & 78 & & \\
\hline Gender & $\begin{array}{l}39.4 \% \\
\text { Male }\end{array}$ & $\begin{array}{l}60.6 \% \\
\text { Female }\end{array}$ & $\begin{array}{l}42.3 \% \\
\text { Male }\end{array}$ & $\begin{array}{l}57.7 \% \\
\text { Female }\end{array}$ & 0.425 \\
\hline Side & $\begin{array}{l}46.5 \% \\
\text { Right }\end{array}$ & $\begin{array}{l}53.5 \% \\
\text { Left }\end{array}$ & $\begin{array}{l}41 \% \\
\text { Right }\end{array}$ & $\begin{array}{l}59 \% \\
\text { Left }\end{array}$ & 0.307 \\
\hline $\begin{array}{l}\text { BMI (body mass } \\
\text { index) }\end{array}$ & 26.73 & 3.5 & 26.44 & 3.3 & 0.438 \\
\hline
\end{tabular}


Table 2: Results of the 2019 and 2020 groups

\begin{tabular}{|c|c|c|c|c|c|}
\hline Variable & \multicolumn{2}{|l|}{2019} & \multicolumn{2}{|l|}{2020} & $P$ value \\
\hline \multicolumn{5}{|l|}{ Fracture type } & \multirow{4}{*}{0.474} \\
\hline $31 \mathrm{~A}$ & \multicolumn{2}{|c|}{$41(57.7 \%)$} & \multicolumn{2}{|c|}{$48(61.5 \%)$} & \\
\hline 31B & \multicolumn{2}{|c|}{$19(26.8 \%)$} & \multicolumn{2}{|c|}{$23(29.5 \%)$} & \\
\hline $31 \mathrm{C}$ & \multicolumn{2}{|c|}{$11(15.5 \%)$} & \multicolumn{2}{|l|}{$7(9 \%)$} & \\
\hline \multicolumn{5}{|l|}{ Treatment } & \multirow{5}{*}{0.788} \\
\hline Conservative & \multicolumn{2}{|c|}{$2(2.8 \%)$} & \multicolumn{2}{|c|}{$3(3.8 \%)$} & \\
\hline Partial prosthesis & \multicolumn{2}{|c|}{$50(70.4 \%)$} & \multicolumn{2}{|c|}{$59(75.6 \%)$} & \\
\hline Cannulated screw & \multicolumn{2}{|c|}{$6(8.5 \%)$} & \multicolumn{2}{|c|}{$4(5.1 \%)$} & \\
\hline Proximal femoral nail & \multicolumn{2}{|c|}{$13(18.3 \%)$} & \multicolumn{2}{|c|}{$12(15.4 \%)$} & \\
\hline \multicolumn{5}{|l|}{ Anaesthesia type } & \multirow{3}{*}{0.936} \\
\hline Spinal & $66(93$. & $\%)$ & $72(92$. & & \\
\hline General & \multicolumn{2}{|c|}{$3(4.2 \%)$} & \multicolumn{2}{|c|}{$3(3.8 \%)$} & \\
\hline \multirow{2}{*}{$\begin{array}{l}\text { Time from admission } \\
\text { to operation (days) }\end{array}$} & Mean & SD & Mean & SD & \multirow{2}{*}{0.101} \\
\hline & 2.26 & 1.73 & 2.19 & 2.7 & \\
\hline $\begin{array}{l}\text { Length of stay in } \\
\text { hospital (days) }\end{array}$ & 6.18 & 3.21 & 6.34 & 4.28 & \\
\hline $\begin{array}{l}\text { Pulmonary } \\
\text { complications }\end{array}$ & 7 & & 12 & & \\
\hline $\begin{array}{l}\text { Venous } \\
\text { thromboembolism }\end{array}$ & 3 & & 3 & & 0.632 \\
\hline Dislocation & 1 & & 0 & & \\
\hline Deep tissue infection & 2 & & 3 & & \\
\hline $\begin{array}{l}\text { Intensive Care Unit } \\
\text { admission }\end{array}$ & 24 & & 29 & & \\
\hline Mortality & 5 & & 8 & & \\
\hline
\end{tabular}

\section{DISCUSSION}

The most significant finding of this study was that the incidence of hip fractures did not decrease during the COVID-19 pandemic. Although a decrease in the incidence of fracture of several bones has been reported to be related to reduced activity, it is a common finding that hip fracture incidence was not decreased in the pandemic $[4,7,8,10]$. Lv et al reported that the incidence of fractures in general was lower in a 1-month period of the pandemic compared to the previous year [10]. A more recent study also reported that the general incidence of fractures decreased in a period of approximately 40 days in the pandemic [1]. In a study by Nunez et al, although it was reported that the incidence of fractures in an 80day pandemic period was lower than the incidence of traumatic fractures in 4 periods of 20 days in the previous year, the incidence of hip fractures was not decreased, as in the current study [11]. No study could be found in literature which compared how fracture incidence had changed in a 6-month period of the pandemic, and the longest study that could be found was of an 80-day period [4].

The adoption of more sedentary lifestyle habits of people under prolonged quarantine conditions leads to a reduction in body muscle mass, and an increase in fatty tissue and BMI [12]. Another result of reduced physical activity is osteoporosis [13]. Increased BMI alone variable when taken as a factor, it reduces the risk of fractures[14]. But in people with the same bone mineral densitometry Increased BMI has been shown to increase fracture risk [15]. Together with the increased risk of fracture, the postoperative complication rate has also been reported to increase in individuals with high BMI [16].

It is known that the patient group where mortality is seen most with pneumonia in COVID-19 infection is the elderly population [17]. In parallel with this, it has been reported that mortality rates have increased during the pandemic without a change in the incidence of hip fractures [8]. Another study reported that there was no change in the hip fracture incidence and mortality rates during the pandemic [7]. In the current study, a numerical increase was seen in mortality rates but this numerical increase was not statistically significant. In a study conducted in 2019 immediately before the pandemic, the in-hospital mortality rate of patients with hip fracture was found to be $3 \%$, and the most common cause of death was reported to be respiratory failure [18]. From this finding, COVID-19 pneumonia can be expected to increase the in-hospital mortality rates of patients with hip fractures.

The current study results showed that the time to surgery of the COVID-19-negative patients in 2020 was shorter compared to the patients in 2019, but the difference was not statistically significant. The time to surgery of the patients preoperatively determined with COVID-19 positivity was found to be statistically significantly longer than that of the COVID-19 negative patients. Although the time to surgery of the COVID-19-negative patients was found to be shorter compared to 2019, no statistically significant reduction was determined. Early surgery and therefore a shorter length of stay in hospital for COVID-19 negative patients is a recommended method to protect the patients 
and their families from COVID-19 infection [19].

In a multi-center study conducted immediately before the pandemic, the outcomes were compared of hip fracture patients applied with an accelerated surgical procedure, patients applied with early surgery and those applied with the standard surgical procedure. The mortality rates were not seen to change in the patients applied with accelerated surgery [20]. A multicentre study of 146 hip fractures during the pandemic reported that mortality rates were increased in patients with delayed surgery and in those treated conservatively [21]. However, no study could be found in literature showing the effect on mortality rates of early surgery applied to patients with COVID-19 positivity, or showing any algorithm for the timing of surgery in these patients.

There were some limitations to this study, primarily that it was conducted in a single center and relatively few patients were evaluated. Therefore, there is a need for further multicentre studies. However, this present study may contribute to national data and/or the systematic reviews and meta-analyzes [22] which will be done together with other studies originating from our country about issue. As bone mineral density values were available for very few of the current study patients, bone mineral density results could not be included in the evaluations. Furthermore, no evaluations could be made of follow-up and mortality rates after discharge, or complications which developed during home care. There was also no evaluation of the mechanism of fracture (fall at home, etc).

\section{CONCLUSION}

Under prolonged pandemic conditions, there is a tendency for more sedentary lifestyle habits, especially in the elderly population. Consequently, decreasing bone quality and increasing BMI are factors increasing the possibility of fracture. To prevent this, it can be recommended that during a period of pandemic there is a need for home exercise programs to be established, and environments should be provided for people to protect their health by leaving their home and taking physical exercise. The creation of a treatment algorithm for the pandemic period specific to the elderly patient group with fractures, primarily hip fracture patients, would be useful in the more productive use of limited economic and human resources, and in the determination of more effective treatment strategies.

Conflict of Interest: The author declares no conflict of interest related to this article.

Funding sources: The author declares that this study has received no financial support

Ethics Committee Approval: Nevşehir Hacı Bektaş Veli University, Ethics Committee. 23/09/2020 / E.8606

Peer-review: Externally and internally peer reviewed.

\section{REFERENCES}

1. Turgut A, Arlı H, Altundağ Ü, Hancıoğlu S, Egeli E, Kalenderer Ö. Effect of COVID-19 pandemic on the fracture demographics: Data from a tertiary care hospital in Turkey. Acta Orthop Traumatol Turc. 2020;54(4):355-63. doi: 10.5152/j.aott.2020.20209.

2. Gallè F, Sabella EA, Ferracuti S, De Giglio O, Caggiano G, Protano C, et al. Sedentary Behaviors and Physical Activity of Italian Undergraduate Students during Lockdown at the Time of CoViD-19 Pandemic. Int J Environ Res Public Health. 2020;17(17):6171. doi: 10.3390/ijerph17176171.

3. Keskek SO, Erdogan H. COVID-19: A Current Brief Review. Acta Med Alanya. 2020;4:197-202. doi: 10.30565/medalanya.747238.

4. Nuñez JH, Sallent A, Lakhani K, Guerra-Farfan E, Vidal N, Ekhtiari S, et al. Impact of the COVID-19 Pandemic on an Emergency Traumatology Service: Experience at a Tertiary Trauma Centre in Spain. Injury. 2020;51(7):1414-8. doi: 10.1016/j.injury.2020.05.016.

5. Çankaya D, Yoldaş B, Çankaya E, Çakir Y, Aydin C, Tabak AY. Analysis of the hip fracture records of a central training and research hospital by selected characteristics. Turk J Med Sci. 2016;46(1):35-41. doi: 10.3906/sag-1406-150.

6. Aslan $\mathrm{A}$, Atay $\mathrm{T}$, Aydoğan $\mathrm{NH}$. Risk factors for mortality and survival rates in elderly patients undergoing hemiarthroplasty for hip fracture. Acta Orthop Traumatol Turc. 2020;54(2):138-43. doi: 10.5152/j.aott.2020.02.298.

7. Macey ARM, Butler J, Martin SC, Tan TY, Leach WJ, Jamal B. 30-day outcomes in hip fracture patients during the COVID-19 pandemic compared to the preceding year. Bone Jt Open. 2020;1(7):415-9. doi: 10.1302/2633-1462.17.BJO-2020-0077.R1.

8. Egol KA, Konda SR, Bird ML, Dedhia N, Landes EK, Ranson RA, et al. NYU COVID Hip Fracture Research Group Increased Mortality and Major Complications in Hip Fracture Care During the COVID-19 Pandemic: A New York City Perspective. J Orthop Trauma. 2020;34(8):395-402. doi: 10.1097/BOT.0000000000001845.

9. Upadhyaya GK, Jain VK, lyengar KP, Patralekh MK, Vaish A. Impact of COVID-19 on post-graduate orthopaedic training in Delhi-NCR. J Clin Orthop Trauma. 2020;11(Suppl 5):S687-95. doi: 10.1016/j.jcot.2020.07.018.

10. Lv H, Zhang Q, Yin Y, Zhu Y, Wang J, Hou Z, et al. Epidemiologic characteristics of traumatic fractures during the outbreak of coronavirus disease 2019 (COVID-19) in China: A retrospective \& comparative multi-center study. Injury. 2020;51(8):1698-704. doi: 10.1016/j.injury.2020.06.022

11. Nuñez JH, Sallent A, Lakhani K, Guerra-Farfan E, Vidal N, Ekhtiari S, et al. Impact of the COVID-19 Pandemic on an Emergency Traumatology Service: Experience at a Tertiary Trauma Centre in Spain. Injury. 2020;51(7):1414-8. doi: 10.1016/j.injury.2020.05.016.

12. Moro T, Paoli A. When COVID-19 affects muscle: effects of quarantine in older adults. Eur J Transl Myol. 2020;30(2):9069. doi: 10.4081/ejtm.2019.9069.

13. Johnell O. Advances in osteoporosis: better identification of risk factors can reduce morbidity and mortality. J Intern Med. 1996;239(4):299-304. doi: 10.1046/j.13652796.1996.429781000.x.

14. Johansson H, Kanis JA, Odén A, McCloskey E, Chapurlat RD, Christiansen C, et al. A meta-analysis of the association of fracture risk and body mass index in women. J Bone Miner Res. 2014;29(1):223-33. doi: 10.1002/jbmr.2017.

15. De Laet C, Kanis JA, Odén A, Johanson H, Johnell O, Delmas P, et al. Body mass index as a predictor of fracture risk: a meta-analysis. Osteoporos Int. 2005;16(11):1330-8. doi: 10.1007/s00198-005-1863-y.

16. Akinleye SD, Garofolo G, Culbertson MD, Homel P, Erez O. The Role of BMI in Hip Fracture Surgery. Geriatr Orthop Surg Rehabil. 2018:12:9:2151458517747414. doi: 10.1177/2151458517747414.

17. Bulut C, Kato Y. Epidemiology of COVID-19. Turk J Med Sci. 2020;50(SI-1):563-70. doi: 
10.3906/sag-2004-172.

18. Groff $H$, Kheir MM, George J, Azboy I, Higuera CA, Parvizi J. Causes of in-hospital mortality after hip fractures in the elderly. Hip Int. 2020;30(2):204-9. doi: 10.1177/1120700019835160.

19. Minarro JC, Zamorano-Moyano C, Urbano-Luque MT, Arenas-de Larriva AP, Izquierdo-Fernández A, Quevedo-Reinoso R. Is COVID-19 affecting the incidence of hip fractures? Injury. 2020;51(10):2329. doi: 10.1016/j.injury.2020.07.018.

20. HIPATTACK Investigators. Accelerated surgery versus standard care in hip fracture (HIP ATTACK): an international, randomised, controlled trial. Lancet. 2020;395(10225):698708. doi: 10.1016/S0140-6736(20)30058-1.

21. Mi B, Chen L, Tong D, Panayi AC, Ji F, Guo J, et al. Delayed surgery versus nonoperative treatment for hip fractures in post-COVID-19 arena: a retrospective study of 145 patients. Acta Orthop. 2020;91(6):639-43. doi: 10.1080/17453674.2020.1816617.

22. Ahmet A. [Systematic Reviews and Meta-Analyses]. Acta Med. Alanya 2018;2(2):6263. DOI: $10.30565 /$ medalanya.439541

\begin{tabular}{|l|l|}
\hline Author / ORCID & Authorship Contrubition \\
\hline $\begin{array}{l}\text { Sefa Aktı } \\
\text { 0000-0001-8873-1358 }\end{array}$ & $\begin{array}{l}\text { Consept and Design, Materials and Practices, } \\
\text { Data collection and Processing, Analysis and } \\
\text { Interpretation, Literatüre Review and Search, } \\
\text { Manuscript Writing and Final approval, }\end{array}$ \\
\hline $\begin{array}{l}\text { Deniz Cankaya } \\
0000-0002-8139-8780\end{array}$ & $\begin{array}{l}\text { Interpretation,Final approval, Süpervision } \\
\text {,Critical Review }\end{array}$ \\
\hline
\end{tabular}

